\title{
Ex Post State Aid Analysis: First Impressions
}

The truth cannot be hidden for long - sooner or later it will be discovered. The witnessing of any misdemeanour, whether intentional or not, draws you in, in the same way that the portrait of Dorian Gray enchanted its owner. In the State aid context, the European Commission requires Member States to paint their own portraits, with forty-five currently in progress. ${ }^{1}$ Thirty-nine evaluation plans are approved by the European Commission, with six currently under consideration, covering 16 Member States and representing an overall annual budget of over $€_{5} \mathrm{obn}^{2}{ }^{2}$ These set the scene for an extensive evaluation, on an ex post basis, of all the vices and virtues of particular aid schemes.

The focus on ex post control was introduced as a result of State aid Modernisation (SAM), the fundamental reform of State aid rules that was designed to streamline processes to enable faster decisions and to focus the European Commission's assessment on those cases that could have the most distortive effects. This major revamp of State aid control was accompanied by greater freedom for Member States to design and implement aid measures and schemes. This greater freedom, however, comes with greater ex post requirements through monitoring and evaluation.

Monitoring is a legal exercise that assesses whether aid awards comply legally with the General Block Exemption Regulation or European Commission approval Decisions. The aim of assessing a sample of cases each year that cover a wide range of Member States and aid objectives is to ensure full legal compliance by Member States in the implementation of the aid, and to identify and remedy any shortcomings in Member States' approaches in order to improve awareness of State aid rules at the national level and to act as a deterrent to prevent non-compliance. ${ }^{3}$

In contrast, the evaluation exercise relies mainly on economic and financial analysis to assess the direct and indirect effects of aid on beneficiaries, including whether the positive effects of the aid outweigh possible negative effects in terms of distortions to competition and trade, in addition to the proportionality and the appropriateness of the aid. Ex post evaluations are required for certain aid schemes with large aid budgets; for those containing novel characteristics; or when significant market, technology or regulatory changes are foreseen. In contrast to ex post monitoring, ex post evaluations are primarily a learning exercise for the European Commission and the Member States. As State aid control was, until 2014, based largely on a system of ex ante scrutiny and assessment, the aim of ex post evaluations is to 'close the circle', and enable the results to be used to improve the design of future State aid measures and schemes. ${ }^{4}$ According to the European Commission,

the benefits of conducting evaluations will materialise within a few years when the first reports are ready and their findings and recommendations are made available to improve the design of subsequent aid schemes and rules. ${ }^{5}$

DOI: $10.21552 / \mathrm{estal} / 2018 / 4 / 3$

1 So far, forty-five evaluation plans have been considered by the European Commission. B Brandtner and D Vidoni, 'State aid Evaluation: State of Play and Ways Forward' (2018) 17 European State Aid Law Quarterly.

2 B Brandtner and D Vidoni, 'State aid Evaluation: State of Play and Ways Forward' (2018) 17 European State Aid Law Quarterly 475.

3 M Muñoz de Juan, 'Monitoring of State Aid: From Ex Ante to Ex Post Control' (2018) 17 European State Aid Law Quarterly 483.

4 European Commission (2014), 'You can't improve what you can't measure: State aid evaluation,' Competition policy brief, June, Issue 7, available at: <http://ec.europa.eu/competition/publications/cpb/2014/007_en.pdf>, accessed on 2 December 2018.

5 European Commission (2014), 'You can't improve what you can't measure: State aid evaluation,' Competition policy brief, June, Issue 7, available at: <http://ec.europa.eu/competition/publications/cpb/2014/007_en.pdf>, accessed on 2 December 2018. 
An important element of ex post evaluations is the assessment of the competitive effects of the aid. Although State aid control is designed to ensure fair competition across the EU, an extensive competitive assessment of the impact of the aid is not always undertaken. However, with the introduction of ex post evaluations, State aid control may be brought more into line with other areas of competition policy, such as merger control, anticompetitive agreements, or abuse of dominance, where competitive assessments are at the heart of the practice. In this context, Oxera was asked by the European Commission to develop an economic framework that could be used to assess the competitive effects of aid, and also to apply the framework to aid previously approved by the European Commission in order to provide further insights into the actual, ex post, impact of aid on competition. ${ }^{6}$

The picture of Dorian Gray gave its owner an opportunity to see his true self. In a similar way, the decentralisation of State aid control will allow aid schemes to be objectively assessed. Hopefully the results will turn out to be just as flawless as Dorian Gray's character was at the very beginning. However, even if the evaluations do identify limitations, the European Commission and the Member States will have a chance to paint new and improved pictures in the future.

Nicole Robins

6 See Oxera (2017), 'Ex post assessment of the impact of state aid on competition', Final report, November, available at <http://ec.europa.eu/ competition/publications/reports/kd0617275enn.pdf>, accessed on 2 December 2018. 